\title{
Association of the wheat stem sawfly with basin wildrye
}

BERTA A. YOUTIE AND JAMES B. JOHNSON

\section{Abstract}

The association of the wheat stem sawny (Cephus cinctus Nort., Hymenoptera:Cephidae) and basin wildrye (Elymus cinereus Scribn. Merr) was investigated in 2 wildrye stands in southern Idaho during the summers of 1982 and 1983 . From 62 to $88 \%$ of wildrye plants were infested with the sawny at the Idaho National Engineering Laboratory and Craters of the Moon National Monument. Plant phenology was a good predictor of sawily emergence. Larvae that developed within culms consumed vascular tissues and may have impaired transport of water and carbohydrates. Seed weight and the number of caryopses developing within wildrye florets were significantly reduced in culms containing sawfly larvae ( $P<0.006$ and $P<0.018$, respectively). Germination rates of seeds from infested and non-infested culms were not significantly different $(P>0.05)$.

Insects are one of the most poorly understood components of range ecosystems (Watts et al. 1982). Biological control programs for rangeland improvements have focused attention on the importance of insect herbivory to range management (Tiernan 1978). Insect seed predators may substantially reduce native plant seed pools or reduce the success of rangeland seedings (Youtie and Miller 1986). Other phytophagous and entomophagous insects may indirectly affect the reproductive potential of a plant species, but their effects may not be easily recognized.

Relatively few insects other than grasshoppers (Orthoptera:Acrididae) and grassbugs, Irbisia and Labops spp. (Hemiptera:Miridae) have been shown to influence growth and development of rangeland grasses. Little is known of the insect fauna of native grasses such as Great Basin wildrye (Elymus cinereus Scribn. \& Merr). Excessive spring grazing by domestic livestock has greatly reduced the abundance of this valuable perennial bunchgrass that is adapted to both highly saline and nonsaline soils (Young and Evans 1981). Restoring rangelands to optimum productivity may require seeding of many wildrye species. Knowledge of the insects associated with wildrye and their potential to reduce forage and seed production may influence the revegetation success of these species.

The wheat stem sawfly, Cephus cinctus Nort., a known economic pest of cereal grains, infests basin wildrye and many other native grasses (Ainslie 1920). Larvae consume parenchyma and vascular tissues within the culms, eventually cut the stems, and overwinter in the remaining stubs (Holmes 1954). Holmes (1977) and others have found reductions in the number of wheat (Triticum aestivum L.) kernels per inflorescence and in the weight of each seed head in sawfly infested stems (Seamans et al. 1944). Impacts of the wheat stem sawfly on native grasses have not been addressed.

The objectives of this study were: (1) to correlate the phenological development of the sawfly and basin wildryre; (2) to determine the degree of sawfly infestation in wildrye stands; and (3) to assess the impact of sawfly tunnelling in the culms on the seed crop.

\section{Methods and Materials}

The study areas were located on the Snake River Plain in south-

\footnotetext{
Authors are assistant land steward with the Nature Conservancy, 1205 NW 25th Avenue, Portland, Ore. 97210; and associate professor, Department of Plant, Soil and Entomological Sciences, University of Idaho, Moscow, Idaho 83843.

Published with the approval of the Director of the Idaho Agricultural Experiment Station as Research Paper No. 87756.

Manuscript accepted 9 February 1988.
}

eastern Idaho on a portion of the Idaho National Engineering Laboratory Site (INEL) and on Craters of the Moon National Monument (CRMO). The region is semi-arid with most of the annual precipitation (INEL-246 mm; CRMO-426 mm) occurring during the winter and spring. Temperatures range from $40^{\circ} \mathrm{C}$ in the summer to $-10^{\circ} \mathrm{C}$ in the winter.

On the study area at INEL, basin wildrye occurred in a depression that was usually flooded in the spring (McBride et al. 1978). The stand covered 1.1 ha at an elevation of $1,475 \mathrm{~m}$ and was surrounded by better-drained soils that supported plant communities dominated by Wyoming big sagebrush, Artemisia tridentata subsp. wyomingensis Beetle and Young.

The CRMO site was a higher elevation $(1,817 \mathrm{~m})$, wet meadow habitat in the mountain big sagebrush, $A$. tridentata subsp. vaseyana (Rydberg) Beetle, zone. This 8.5 -ha site supported nearly a pure stand of basin wildrye.

Phenological development of the wheat stem sawfly and basin wildrye were monitored from 25 May through 20 August in 1982 and 1983. Each spring, 30 wildrye stubs (the lower portion of the culms $(\mathrm{ca} .10 \mathrm{~cm})$ left standing after the sawfly larvae cut the culms in the fall to create overwintering sites) were randomly collected twice weekly; the phenological stage and mortality of the sawflies were recorded. After emergence of adult sawflies, green culms were split and larval instars were recorded. Live larvae and pupae of the sawfly and parasites were reclosed within the split stem and placed in cotton stoppered shell vials $(9 \times 80 \mathrm{~mm})$. The vials were then labelled and placed in widemouth $500 \mathrm{cc}$ jars containing a saturated salt $(\mathrm{NaCl})$ solution to maintain $80 \%$ relative humidity. Emergence of adult sawflies and parasites were recorded.

To determine sawfly infestation rates, each study area was divided into square quadrants. Each quadrant was $225 \mathrm{~m}^{2}$ in size. Twice weekly, randomly oriented $15-\mathrm{m}$ transects were established in randomly chosen quadrats. Five culms from the bunchgrass nearest each meter mark on the transect were sampled. Culms were split longitudinally and insect larvae were collected.

To assess the impact of $C$. cinctus on Elymus seed production, seed heads were collected at INEL; seeds at CRMO were only in the milk stage at the end of the sampling season, and therefore, were not collected or analyzed for effects of herbivory.

At seed maturity, plants were selected randomly along 50-m transects. Five culms per plant were sampled until approximately 500 sawfly infested culms and 500 uninfested culms were collected. Stem diameter was measured $1 \mathrm{~cm}$ above the first internode. The entire spike from each culm was placed into an individual paper sack. Each stem was split longitudinally and examined for the presence of a sawfly larva.

Percent seed fill was estimated by determining the number of seeds present in 3 subsamples of 10 randomly chosen florets from each of the 1,009 spikes collected. Seed weight was estimated by weighing 3 subsamples of 10 seeds from each spike.

Twenty samples of 25 seeds from sawfly infested and noninfested tillers were utilized to calculate germination rates. Seeds were placed in a germinator at $20^{\circ} \mathrm{C}$ without light as recommended for the basin wildrye cultivar 'Magnar' (Evans and Young 1983). Percent germination as determined at 1 and 2 weeks.

Analysis of variance and $t$-tests were used to test for differences in percent seed fill, seed weight, percent germination, and culm diameter between infested and non-infested culms. 


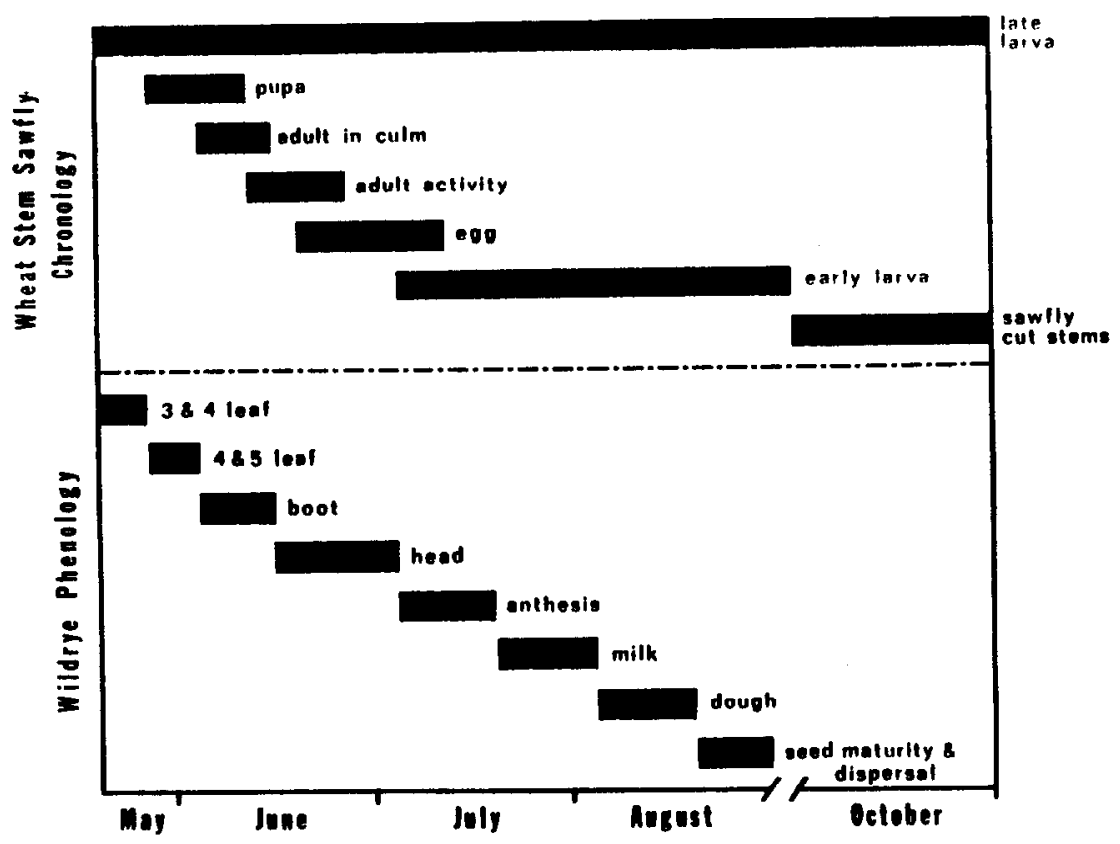

Fig. 1. Phenological development of the wheat stem sawfly and its host, basin wildrye, Idaho National Engineering Laboratory, 1983.

\section{Results}

From 62 to $88 \%$ of Basin wildrye plants were infested with the wheat stem sawfly at the 2 study sites (Table 1 ). The infestation rate for individual tillers ranged from 22 to $38 \%$. Infestation rates tended to be greater at INEL than CRMO in both years, but these differences were not significant $(P>0.05)$. There were no significant differences $(P>0.05)$ between years at either site.

Table 1. Percent infestation of basin wildrye by the wheat stem sawfly at the Idaho National Engineering Laboratory (INLL) and Craters of the Moon National Monument (CRMO), Idaho, in 1982 and 1983.

\begin{tabular}{|c|c|c|c|c|}
\hline \multirow[b]{2}{*}{ Year } & \multirow[b]{2}{*}{ Location } & \multicolumn{2}{|c|}{ Mean Percent Infestation } & \multirow[t]{2}{*}{ Plant Density } \\
\hline & & Plants & Tillers & \\
\hline & & $\%\left(\mathrm{SD}, \mathrm{N}^{1}\right)$ & $\%(\mathrm{SD}, \mathrm{N})$ & Tillers $/ \mathrm{m}^{2}(\mathrm{SD}, \mathrm{N})$ \\
\hline \multirow[t]{2}{*}{1982} & INEL & $88(15.9,12)^{*}$ & $27(10.5,12)$ & --2 \\
\hline & CRMO & $73(16.3,6)$ & $22(11.7,6)$ & --- \\
\hline \multirow[t]{2}{*}{1983} & INEL & $79(13.7,6)$ & $38(13.0,6)$ & $191(242,448)$ \\
\hline & CRMO & $62(17.3,4)$ & $22(8.4,6)$ & $391(364,325)$ \\
\hline
\end{tabular}

*No significant differences in mean percent infestation rates between years or sites according to Tukey's t-test $P>.05$.

${ }^{1} \mathrm{~N}=$ number of samples of 75 tillers from 15 plants.

2No samples taken in 1982 .

Total $C$. cintus larval mortality and parasitism tended to be greater at CRMO than the INEL (Table 2). Percentage of larvae found dead due to causes other than parasitism was significantly different between the 2 sites $(P<0.05)$. However, there were no significant differences in percent parasitism $(P>0.05)$. An eulophid wasp, Pediobius utahensis (Crawford), was the parasite collected and reared from the grass stubs at both sites.

Development of the wheat stem sawfly and basin wildrye at INEL was about 3 weeks ahead of CRMO. However, the phenological relationship between the insect and plant was very similar at both sites; therefore, only data from the INEL site are presented (Fig. 1).

When monitoring began at INEL in 1983, plants were in the 3-or 4-leaf stage. The sawflies were all larvae on 25 May, having overwintered in the last larval instar in grass stubs. By this time, the obligatory diapause (completed after a minimum of 90 days at $10^{\circ} \mathrm{C}$
Table 2. Percent mortality of the wheat stem sawfly in basin wildrye stubs at the Idaho National Engineering Laboratory (INEL) and Craters of the Moon National Monument (CRMO), Idaho, in 1983.

\begin{tabular}{lcc}
\hline & \multicolumn{2}{c}{ Mean Percentage Mortality } \\
\cline { 2 - 3 } Location & Non-Parasite Induced & Parasite Induced \\
\hline & $\%(\mathrm{SD}, \mathrm{N} 1)$ & $\%(\mathrm{SD}, \mathrm{N})$ \\
INEL & $9.6(7.3,16) \mathrm{a}^{*}$ & $2.1(4.0,16) \mathrm{a}$ \\
CRMO & $15.6(9.5,18) \mathrm{b}$ & $5.6(8.0,18) \mathrm{a}$ \\
\hline
\end{tabular}

* Mean percent mortality in columns followed by similar lower case letters are not significantly different according to Tukey's t test $P \leq .05$ level.

in = number of samples consisting of 15 larvae.

2Primarily Pediobius utahensis Crawford.

(Salt 1946)) was completed and larvae were observed pupating in late May and early June. However, $10 \%$ of the population at INEL did not pupate and remained in the larval form during the entire monitoring period. This 2-year life-cycle was not observed at the CRMO site.

In June, adult sawflies emerged by chewing a hole at the top of the stub. Adult activity was observed for approximately 2 weeks at each site. Female sawflies deposited eggs in the stems during the plants' boot and heading out stages. The majority of eggs were deposited in the third internode. Each female deposits only $1 \mathrm{egg}$ per stem, but several females may oviposit in the same stem (Holmes 1977). Because larvae are cannibalistic, only 1 larva survives per stem (Seamans et al. 1944). Internal plant tissues were consumed while seeds were forming on the spike. As the stems began to drain in mid-August, the larvae moved downward, cut the stems, and placed plugs of grass in the exposed ends of the remaining stubs. There, the larvae formed cocoons, and over-wintered. Seeds were mature before the larvae cut the stems.

Sawflies tended to select larger grass culms for oviposition. Mean culm diameter was significantly larger $(P<0.001)$ for sawfly infested stems than for non-infested stems, with means of $2.67 \mathrm{~mm}$ and $2.36 \mathrm{~mm}$ and sample size of $\mathbf{4 8 4}$ and 525 , respectively. Therefore, seed set and seed weight were examined in 4 stem diameter classes.

Mean seed weights increased as stems became larger. The percent reduction in seed weight of infested culms remained constant 


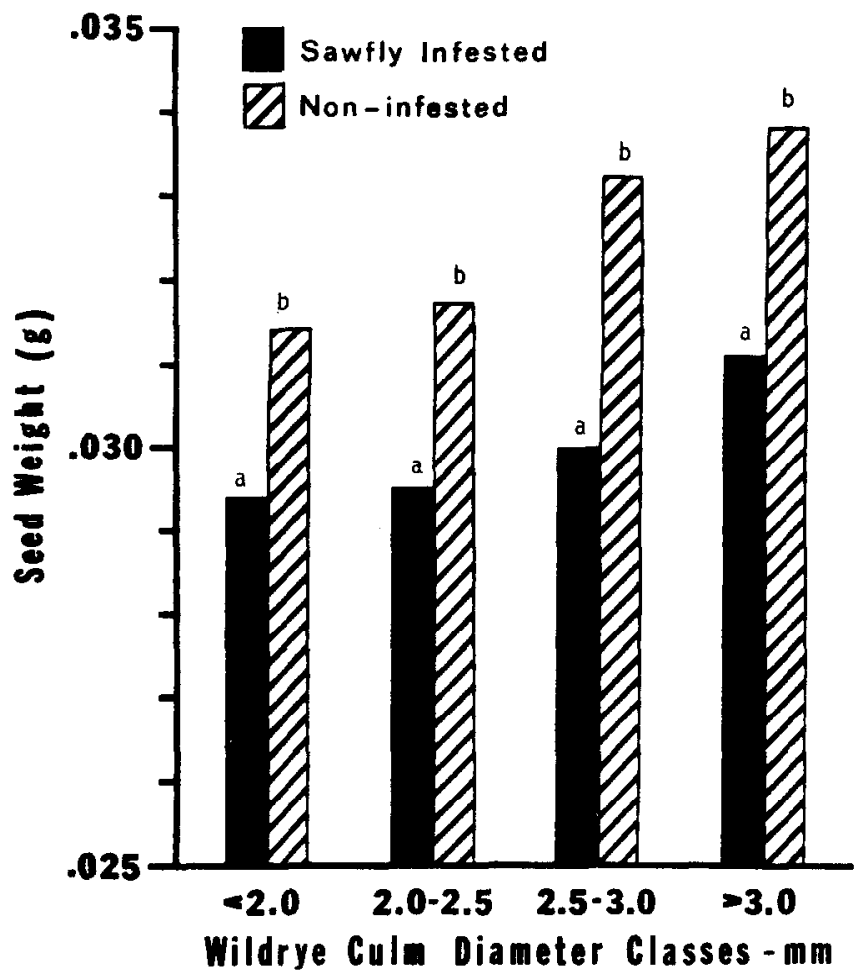

Fig. 2. Mean weight of 10 seeds from basin wildrye tillers infested and non-infested with the wheat stem sawfy. Idaho National Engineering Lab., 1983. Different letters within diameter classes represent significant differences ( $\mathrm{p} \leq 0.006 ; 2-w a y$ ANOVA, Tukey's t test).

over all 4 size classes (Fig. 2). Infested stems in all size classes showed significantly lower seed weights $(p<0.006)$. The average weight reduction was $8.5 \%$ over all classes.

Larger stems did not necessarily result in greater seed fill for uninfested stems (Fig. 3). Infested stems showed a significant $(p<0.018)$ reduction in seed fill, $(c a .8 \%)$, averaged over all size classes. However, infestation did not yield a constant reduction in seed fill over all diameter classes. Percent seed set decreased with increasing stem size in infested stems, but varied little in noninfested stems.

Germination rates of basin wildrye are normally quite low (Young and Evans 1981). In this study, less than 50\% of the seeds germinated after 2 weeks in the germinators (Table 3). Tests were

Table 3. Percent germination of seeds from whent stem sawily infested and non-infested basin wildrye tillers, Idaho National Engineering Laboratory, 1983.

\begin{tabular}{lcc}
\hline \multirow{2}{*}{ Elasped Time } & \multicolumn{2}{c}{ Mean Percent Seed Germination } \\
\cline { 2 - 3 } & Infested Tillers & Non-infested Tillers \\
\hline week & $33.2(9.6,20)$ & $\%(\mathrm{SD}, \mathrm{N})$ \\
2 weeks & $44.6(10.2,20)$ & $29.4(8.6,20)$ \\
\end{tabular}

* There are no significant differences in percent seed germination between infested and non-infested tillers during 1 week $(t=1,31, t 0.05(2) 38=2.02)$ and 2 weeks $(t=1.33, t 0.05(2)$ $38=2.02 ; s d=$ standard deviation and $n=20$ petri dishes of each treatment with 25 seeds per dish.

then terminated due to mold growth on some of the seeds. No significant differences $(p<0.05)$ were found between the germination rates of seeds from infested and non-infested tillers.

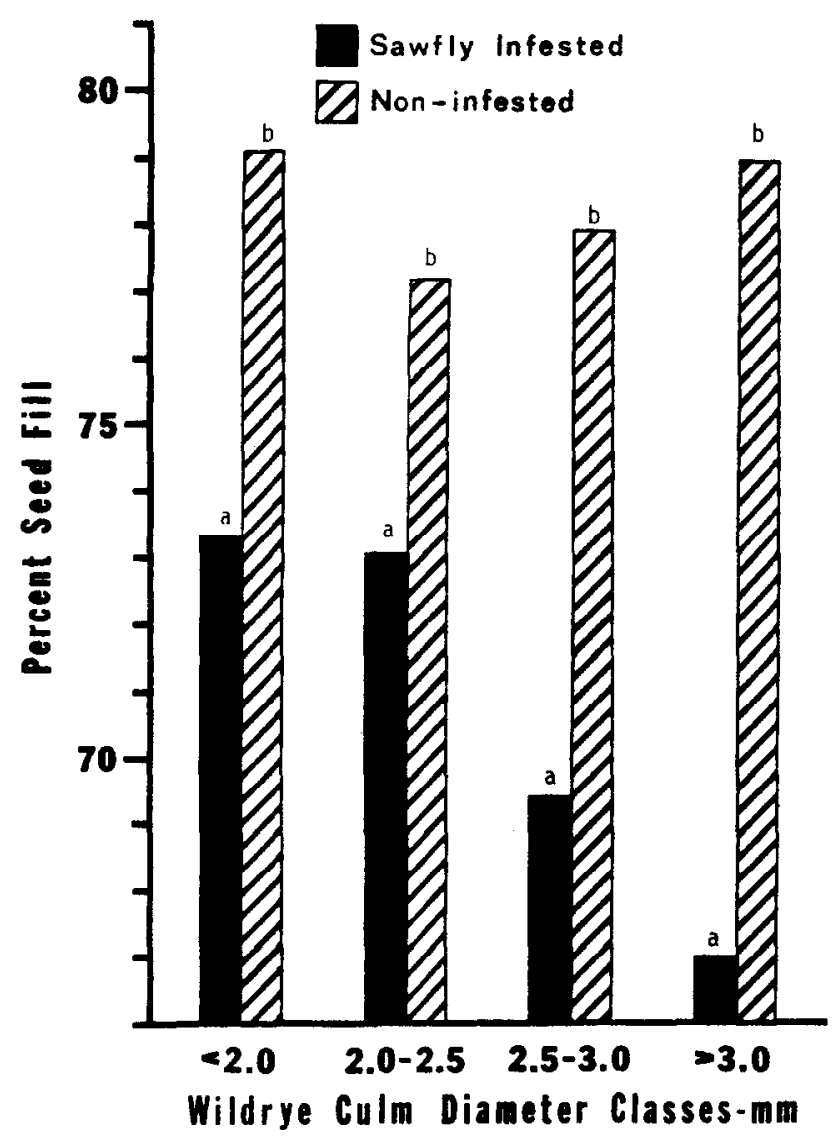

Fig. 3. Mean percent seed set of basin wildrye tillers infested and noninfested with the wheat stem sawfly, Idaho National Engineering Lab., 1983. Different letters within diameter classes represent significant differences ( $\leq \leq 0.018 ; 2-w a y$ ANOVA, Tukey's t-test).

\section{Discussion}

A large percentage of basin wildrye tillers were infested with the wheat stem sawfly in southern Idaho. Wildrye phenology was a valuable predictor of adult sawfly emergence. Insects emerged in both years and on both sites when wildrye was in the late boot and heading out stages.

Synchrony between plant phenology and herbivore feeding affects both the success of the herbivore and the type of response from the plant (Crawley 1983). Most damage occurred to basin wildrye after the inflorescence had been formed, but before most of the translocation from the stem to the spike occurred (Rawson and Evans 1971). Spikelet number was differentiated in the floral primordia (Rawson 1969) before sawfly injury; however, the number of caryopses was reduced (Fig. 3).

Sawfly herbivory reduced the number of seeds produced and their mean weight. Sawfly consumption of vascular tissues in the stem likely imposed a severe physiological stress on the culms by reducing the carbohydrates available for growth and respiration. In wheat, most of the carbohydrates for seed development come from the flag leaf and the head itself (Bewley and Black 1978). Rawson and Evans (1971), reported that $12.2 \%$ of grain weight was provided by stem material through translocation. The net reduction in total seed weight (8.5\%) of basin wildrye found in this study is comparable with their figure.

Sawfly tunnelling may also impair water translocation. Premature drying of infested stems was observed. Under drought stress, 
stems increase their contribution to grain development. Holmes (1977) observed a greater reduction of grain weight in sawfly infested wheat stems in years of reduced precipitation. Asana and Basu (1963) studied the effects of water stress on grain development and reported that the transport of stem sugars to the head was inhibited and that photosynthetic activity was reduced resulting from premature drying of the spike and stem. Similar mechanisms may operate in basin wildrye.

The germination rate of the smaller seeds from sawfly infested wildrye stems was not significantly different $(P>0.05)$ from the larger seeds of non-infested stems. However, many authors have substantiated the important role of larger seeds in increasing seedling survival (Winn 1985, Stanton 1984, Maun and Cavers 1971, Twamley 1967, Kneebone and Cremer 1955, Rogler 1954). The mass of the endosperm food reserves is an important characteristic associated with plant vigor (McKell 1972). Even a small reduction in seed weight has been shown to place a seedling at a severe competitive disadvantage (Harper et al. 1970). However, in some cases, small seeds may have advantages. They may germinate more rapidly. Time of emergence can have an important effect on seedling success (Howell 1981, Ross and Harper 1972). Smaller seeds may also be subject to less predation, have different dispersal potentials, and more easily and up in suitable safe sites for germination (Capinera 1979).

Plants that alter their reproductive output are more likely to reduce seed number than seed size (Harper 1977). A sawfly induced reduction in the number of seeds may reduce the chances for successful seedling establishment. With fewer seeds produced, it is less likely that some will escape predation, and land in safe sites to germinate.

Although the wheat stem sawfly may significantly affect the basin wildrye seed crop in the statistical sense, it may not be biologically significant. Because basin wildrye is a perennial bunchgrass, vegetative reproduction plays a much greater role in its population dynamics than does sexual reproduction in established stands. Impact may be more important in Elymus grown as a seed crop. Also, compensatory growth responses of plants after herbivore damage may mitigate any deleterious effects of herbivory (Vickery 1972; McNaughton 1979, 1983). Tillers without sawflies may have had greater access to the pool of carbohydrates and the available water supply due to the impairment of the sawfly infested tillers. The uninfested tillers may have compensated for the reduction in seed production in the infested tillers with increased seed numbers and seed size. Therefore, on a per plant basis, there may not have been a decrease in the basin wildrye seed crop.

To fully understand the impact of wheat stem sawfly feed on basin wildrye, additional work will be needed. Controlled experiments eliminating the sawfly from entire bunchgrass plants are essential. Plants with few tillers could be infested with the sawfly to examine tiller compensation.

\section{Literature Cited}

Ainslie, G.G. 1920. The western grass-stem sawfly. USDA Bull. 481.

Asana, R.D., and R.N. Basu. 1963. Studies in physiological analysis of yield. Indian J. Plant Physiol. 6:1-13.

Bewley, J.D., and M. Black. 1978. Filling of the grain in cereals. In: Physiology and biochemistry of seeds. Vol. I. Development, germination and growth. Springer-Verlag, Berlin.
Crawley, M. 1983. Herbivory: The dynamics of animal-plant interactions. Univ. of Calif. Press, Berkeley, Calif.

Evans, R.A., and J.A. Young. 1983. 'Magnar' Basin wildrye germination in relation to temperature. J. Range Manage. 36:395-398.

Harper, J.L., P.H. Lovell, and K.G. Moore. 1970. The shapes and sizes of seeds. Annu. Rev. of Ecol. and Syst. 1:327-356.

Holmes, N.D. 1954. Food relations of the wheat stem sawfly, Cephus cinctus Nort. (Hymenoptera: Cephidae). Can. Entomol. 86:159-167.

Holmes, N.D. 1977. The effect of the wheat stem sawfly, Cephus cinctus (Hymenoptera: Cephidae), on the yield and quantity of wheat. Can. Entomol. 109:1591-1598.

Holmes, N.D. 1982. Population dynamics of the wheat stem sawfly, Cephus cinctus (Hymenoptera: Cephidae), in wheat. Can. Entomol. 114:775-778.

Howell, N. 1981. The effect of seed size and relative emergence time on fitness in a natural population of Impatiens capensis Meerb. (Balsaminaceac). Amer. Midl. Natur. 105:312-320.

Kneebone, W.R., and C.L. Cremer. 1955. The relationship of seed size to seedling vigor in some native grass species. Agron. J. 47:472-477.

Maun, M.A., and P.B. Cavers. 1971. Seed production and dormancy in Rumex crispus. I. The effects of removal of cauline leaves at anthesis. Can. J. Bot. 49:1123-1130.

McBride, R., and N.R. French, A.H. Dahl, J.E. Detmer. 1978. Vegetation types and surface soils of the Idaho National Engineering Laboratory Site. U.S.D.O.E., Radiol. Environ. Sci. Lab. Rep. IDO-12084, Idaho Falls, Idaho.

McKell, C.M. 1972. Seedling vigor and seedling establishment. p. 76-89. In: V.B. Younger and C.M. McKell (eds.), The biology and utilization of grasses. Academic Press, New York.

MeNaughton, S.J. 1979. Grassland-herbivore dynamics. p. 46-81. In: Sinclair, A.R. and M. Norton-Griffiths (eds.), Serengeti: Dynamics of an ecosystem. Univ. Chicago Press, Chicago.

McNaughton, S.J. 1983. Compensatory plant growth as a response to herbivory. Oikos 40:329-336.

Rawson, H.M. 1970. Spikelet number, its control and relation to yield per ear in wheat. Austral. J. Biol. Sci. 23:1-15.

Rawson, H.M., and L.T. Evans. 1971. The contribution of stem reserves to grain development in a range of wheat cultivars of different heights. Austral. J. Agr. Res. 22:851-863.

Rogler, G.A. 1954. Seed size and seedling vigor in crested wheatgrass. Agron. J. 46:216-220.

Ross, M.A., and J.L. Harper. 1972. Occupation of biological space during seedling establishment. J. of Ecol. 60:77-88.

Sult, R.W. 1946. Some effects of temperature on the production and elimination of diapause in the wheat stem sawfly, Cephus cinctus Nort. Can. J. of res. 25:66-85.

Seamans, H.L., G.F. Manson, and C.W. Farstad. 1944. The effect of wheat stem sawfly (Cephus cinctus Nort.) on the heads and grain of infested stems. 75th Ann. Rep. Entomol. Soc. Ont.

Stanton, M.L. 1984. Seed variation in wild radish: Effect of seed size on components of seedling and adult fitness. Ecology. 65:1105-1112.

Tiernan, C.F. 1978. The role of entomology in range management. Proc. 1st Int. Rangeland Cong. USDA U.S. Forest Serv. p. 477-478.

Twamley, B.E. 1967. Seed size and seedling vigor in birdsfoot trefoil. Can. J. Plant Sci. 47:603-609.

Vickery, P.J. 1972. Grazing and net primary production of a temperate grassland. J. Appl. Ecology. 9:307-314.

Watts, J.G., E.W. Huddleston, and J.C. Owens. 1982. Rangeland entomology. Annu. Rev. Entomol. 27:283-311.

Winn, A.A. 1985. Effects of seed size and microsite on seedling emergence of Prunella vulgaris in 4 habitats. J. Ecol. 73:831-840.

Young, J.A., and R.A. Evans. 1981. Germination of Great Basin wildrye seeds collected from native stands. Agron. J. 73:917-920.

Youtie, B.A., and R.F. Miller. 1986. Insect predation on Astragalus filipes and $A$ purshii seeds. N.W. Science 60:42-46. 